\section{Organic Vegetable Crop Production in Controlled Environments Using Soilless Media}

\author{
Mary A. Rogers ${ }^{1}$
}

ADDITIONAL INDEX wORDs. hydroponics, substrate, controlled-environment agriculture, compost

SUMMARY. Organic vegetables produced in greenhouses and other controlled environments may fill a unique market niche as consumers demand local, high vegetables year round. However, limited technical information supports these production systems and more research is needed to provide recommendations for appropriate substrate mixes and nutrient management. Compost can be used as a substitute for peat-based media, and research results vary widely based on feedstock, compost method, and proportion used in mixes. Most studies consider compost in terms of peat-substitute or replacement and not as a source of fertility in soilless systems. Common challenges in using compost in soilless media are due to immaturity of the compost, poor water holding capacity, and unbalanced salinity and $\mathrm{pH}$. It is possible to certify organic soilless production systems; however, the National Organic Program (NOP) of the U.S. Department of Agriculture has not yet provided clear rules and requirements supporting these systems. The objective of this article is to review the literature on soilless organic vegetable production, summarize results from the more widely studied topic of vegetable transplant production, and point to future research for organic agriculture.

$\mathrm{O}$ rganic vegetable production under glass or in other protected environments, hereto referred as controlled-environment agriculture (CEA) is growing, according to the 2014 census of organic agriculture reported by the U.S. Department of Agriculture (USDA, 2015). According to this recent census, there were about 1500 certified or exempt organic farms producing vegetables, potatoes (Solanum tuberosum), and melons (Cucumis sp.) under glass or plastic, representing \$76 million in sales. Although still a niche compared with the entire specialty crop industry in the United States, this represents a $28 \%$ increase in the number of farms using protected culture since 2008 (USDA, $2012,2015)$. The previous 2008 census pooled organic floriculture, bedding, and nursery crops, as well as mushrooms and all other food crops

Department of Horticultural Science, University of Minnesota, 1970 Folwell Avenue, St. Paul, MN 55108

This paper was part of the workshop "Soil Health and Implication in Organic Nutrient Management on Vegetable Production" held 5 Aug. 2015 at the ASHS Annual Conference, New Orleans, LA, and sponsored by the Organic Horticulture Working Group.

We thank Sue Wika and Tom Prieve of Paradox Farms and Elizabeth Perkus for the photo used in Figure 1. We also thank Carl Rosen, Heidi Anderson, Andrew Petran, Jared Rubinstein, and Aimee Talbot for reviewing the manuscript.

${ }^{1}$ Corresponding author. E-mail: roge0168@umn.edu doi: 10.21273/HORTTECH03352-16 grown under protected culture, so the actual increases in vegetables grown under protection are likely larger than $28 \%$. In 2014 , the highest value of sales in millions of dollars was fresh market tomatoes [Solanum lycopersicum $(\$ 18.1)$ ], followed by fresh cut herbs (\$5.9), lettuce [Lactuca sativa (\$5.4)], bell peppers [Capsicum annuum $(\$ 1)]$, and spinach [Spinacia oleracea (\$0.5)]. In millions of dollars in sales, the top three leading states in protected culture of organic vegetables are California (\$31.3), Pennsylvania (\$12.2), Massachusetts (\$6.2), New York (\$2.7), Oregon (\$2.6), and Florida (\$2.6) (USDA, 2015). The increase in farms, acreage, and sales of CEA reflects increasing consumer demand for local and organic fresh produce. Simultaneously, there is increasing interest and development of CEA in urban settings, including high tunnels, passive-solar-heated greenhouses, vertical farms, and aquaponics (Despommier, 2011; Ford and Waibel, 2009; Specht et al., 2014; Tyson et al., 2011; Wortman and Lovell, 2013). Faced with a variable and changing climate that contributes to instability in horticultural crop production, increasing the capacity for localized food production will increase food system resiliency (Hodbod and Eakin, 2015) and CEA can help meet this need.

Many different production systems can be categorized as CEA. In high tunnels, crops are often grown directly in the soil, and fertility can be maintained through inputs such as composts, cover crops, and commercially available organic fertilizers (Montri and Biernbaum, 2009). In aquaponics, wastewater from fish production provides nutrients to crops in a media-filled raised bed or floating system (Tyson et al., 2011). Other CEA systems such as vertical farms and passive solar heated greenhouses (Fig. 1) use a hydroponic or soillessmedia-containerized system, where regular applications of nutrients from external sources are required to maintain plant growth and quality. Both water culture and soilless substrate culture are considered "hydroponic" systems; however, this review will focus on the latter, as these are typically the systems of interest to organic producers. Although hydroponic production is not a new concept (Jensen and Collins, 1985), fitting this system into an organic framework has been somewhat controversial. The European Commission prohibits hydroponic production in organic agriculture (International Federation of Organic Agriculture Movements, 2014). In the United States, the National Organic Standards Board (NOSB) recommended in 2010 that the NOP prohibit hydroponic production in organic agriculture, stating that "...based on its foundation of sound management of soil biology and ecology, it becomes clear that systems of crop production that eliminate soil from the system, such as hydroponics or aeroponics, cannot be considered as examples of acceptable organic farming practices" (USDA,

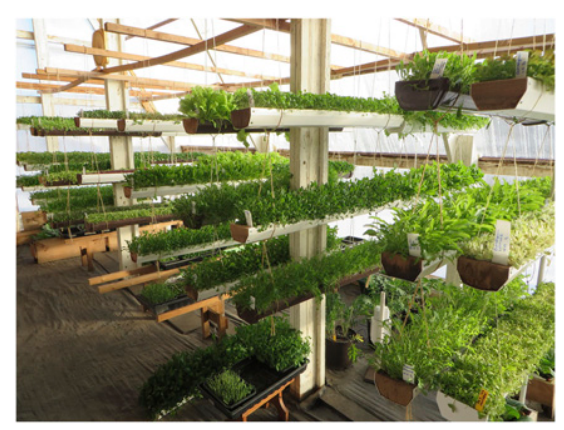

Fig. 1. Lettuce and mustard greens growing in a vertical gutter system in soilless, organic media in a passive solar heated greenhouse at Paradox Farm, Ashby, MN (photo by E. Perkus). 
2010). The implication is that soilless systems are exclusively reliant on synthetic fertility sources and do not benefit from ecosystem functions mediated by microorganisms associated with soil. However, emerging research shows that soilless hydroponic systems using white peat and coconut fiber substrate may support a diverse community of microorganisms that mediate important functions in these systems, including disease suppression, and contribute to productivity and plant quality similar to soil-based systems (Grunert et al., 2016). Hydroponic systems relying on carbon-based substrates may fit within the organic definition. The NOP has not yet established rules and regulations based on the NOSB advisory board recommendation, but certifying agencies may allow hydroponic organic operations based on interpretation of the current regulations (Dixon, 2015). Vegetable seedlings grown for field transplant using soilless media can be marketed as organic without these reservations, provided they are grown in accordance to NOP regulations. Therefore, many vegetable growers in CEA wishing to adhere to organic standards are estimating fertility rates based on conventional fertility recommendations (Zheng et al., 2011). Currently, there are few practical, research-based recommendations supporting organic vegetable production in greenhouses using soilless media. The objective of this article is to review the literature on soilless organic vegetable production systems, summarize the results from the more widely studied topic of vegetable transplant production, and point to future research needs for organic agriculture.

\section{Organic transplant production}

Inputs and media mixes vary as organic growers may use a combination of plant- and animal-based amendments depending on what is available locally (Clark and Cavigelli, 2005; Treadwell et al., 2007). Peatbased media became widely adopted to avoid some of the historic problems using soil, such as limited availability of quality topsoil, poor drainage, presence of weed seed and disease and herbicide residues. These concerns prompted the development of "peat-lite" mixes containing peatmoss, vermiculite and/or perlite (Boodley and Sheldrake, 1977). Peat-based substrates are common in soilless culture; however, peat substitutes have also been evaluated due to concerns with the availability and longterm sustainability of mined peat (Raviv, 2005). A wide variety of substrates can be used for vegetable transplant production, including coir (Cocos nucifera), rice (Oryza sp.) hulls, pine (Pinus sp.) bark, switchgrass (Panicum virgatum), posidonia (Posidonia sp.) residues, and composts (Kuepper and Everett, 2004). The physical and chemical properties of the growing media are important for germination, growth, and quality of vegetable transplants. A high-quality substrate has a carbon: nitrogen ratio between $15: 1$ and 20:1, $\mathrm{pH}$ range of 6.5 to 7 , bulk density within 40 to $60 \mathrm{lb} / \mathrm{ft}^{3}$ (0.64 to 0.96 $\left.\mathrm{g} \cdot \mathrm{cm}^{-3}\right)$, and adequate moisture retention and aeration to support plant development (Nelson, 2012; Sterrett, 2001). Although it holds nutrients well, peat is inert and does not contribute to crop fertility needs. Organic fertility sources for transplant production include fish and seaweed based fertilizers, guano, poultry litter, cottonseed (Gossypium sp.), soybean (Glycine max), and alfalfa (Medicago sativa) meal, bone, feather and blood meal, and rock phosphate (Greer, 2005; Kuepper and Everett, 2004). Tomato transplants grown in a peat-compost growing medium performed equally well $(57 \%$ to $83 \%$ increased shoot dry weight compared with unfertilized control plants) when fertilized with blood, feather, meat, crab shell, fish, cottonseed meal, and dried whey sludge, but poorly when fertilized with wheat bran (Triticum aestivum), alfalfa meal, and canola (Brassica napus) meal (Gagnon and Berrouard, 1994). In another study bell pepper and onion (Allium cepa) transplants were grown organically using three different substrates approved for organic production and containing various materials including peatmoss, compost, and pasteurized topsoil and fertilized with organic $2.1 \mathrm{~N}-3.3 \mathrm{P}-2.2 \mathrm{~K}$ (Sea Tea; Garden-Ville, San Antonio, TX) containing compost tea (Russo, 2005). The organic transplants were compared with a conventional control, grown using commercial medium (ReddiEarth; Scotts-Sierra, Marysville, OH), fertilized with half-strength $20 \mathrm{~N}-$ 8.7P-16.6K water-soluble fertilizer (Peters 20-20-20; Spectrum Group, St. Louis, MO). The results showed that bell pepper typically performed better under conventional practices; however, using the highest rate of Sea Tea with organic growing medium (Sunshine; Sun Gro Horticulture, Bellevue, WA) produced equivalent quality transplants. Quality of onion transplants was equivalent regardless of fertilizer used (Russo, 2005). Transplant quality will vary by crop, substrate, and fertility source. With pure plant-based fertilizers, an incubation period of 2 weeks is recommended to avoid phytotoxicity associated with mineralization (Koller et al, 2004).

Compost can be used successfully as a peat substitute or as a substrate component in vegetable transplant production (Díaz-Pérez et al., 2008; Raviv, 2005; Reis et al., 1998; Sterrett, 2001) and high-quality organic commercial mixes often contain compost, but these can be expensive and difficult to access (C. Ford, personal communication). Growers may create their own compost from locally available materials, but if done improperly can result in high salinity, storage problems, and odors and flies (Matkin and Chandler, 1957; Sterrett, 2001). Using locally available materials as feedstock in compost often results in inconsistent plant quality compared with commercially available mixes, due to the wide range raw materials, the composting method, and how compost is stored. The majority of problems with incorporating compost into media for vegetable transplants are associated with immature compost, high electrical conductivity (EC) and poor water-holding capacity (Sterrett, 2001). To be acceptable for containerized production, composts must be stable and mature so that active microbial decomposition is complete and the compost is free of phytotoxic compounds. If compost is immature, it can immobilize $\mathrm{N}$, inhibit germination, or be phytotoxic. Nitrogen mineralization rates of the feedstock and environmental factors such as moisture, temperature, salinity, and $\mathrm{pH}$ determine the amount of nitrogen available to plants (Sikora and Szmidt, 2001). High salinity is indicated by EC and organic fertilizers contribute to salinity as they mineralize. In sensitive crops, high EC can inhibit germination and cause stunting (Peet et al., 2008). High EC levels have been 
reported from studies incorporating composts as organic amendments (Clark and Cavigelli, 2005; Russo, 2005; Rippy et al., 2004; Sikora and Szmidt, 2001; Zhang et al., 2013). This may or may not result in a negative plant response based on the particular crop, environment, and duration of production, as leaching will mitigate negative effects. Additionally, high $\mathrm{pH}$ has been reported with organic fertility sources (Rippy et al., 2004; Zhang et al., 2013), and can limit nutrient uptake.

Transplant performance in media containing compost is variable and may be based on species of crop, the feedstocks used in the compost, and the relative proportion of compost in the media. Most studies involve tomato and report better results when green waste composts are used for transplant production rather than manure-based composts. Ceglie et al. (2015) showed that the best media for overall transplant quality across three crops tomato, melon (Cucumis melo), and lettuce was a mixture of $20 \%$ green compost \{created from waste from olive (Olea europaea), conifer [pine and spruce (Picea sp.)] tree prunings, and perennial ryegrass (Lolium perenne) clippings\}, 39\% palm (Phoenix sp. and Washingtonia sp.) fiber, and $31 \%$ peat $(\mathrm{v} / \mathrm{v})$. Another study found that a mixture of compost [ $20 \%$ posidonia waste, $40 \%$ grapevine (Vitis sp.) prunings, and $40 \%$ vegetable residues from broccoli (Brassica oleracea var. italica), fennel (Foeniculum vulgare), and celery (Apium graveolens) scraps], containing either $25 \%, 50 \%$, or $75 \%$ (by volume) peat performed equally well for both melon and tomato transplants (Mininni et al., 2013). Tomato transplants grown in $50 \% \mathrm{v} / \mathrm{v}$ compost made from food residue plus yard waste performed as well as peat-based media with synthetic fertilizer, but transplants grown in $50 \%$ (by volume) compost made from horse bedding did not perform well, due to high salinity (Clark and Cavigelli, 2005). In tomato transplant production, compost containing yard trimmings and biosolids as a peat substitute and fertilized with a standard commercial soluble fertilizer $\left(200 \mathrm{mg} \cdot \mathrm{L}^{-1}\right.$ of nitrogen per week) resulted in high quality transplants, but compost quality varied and salinity was problematic in one replicate (Ozores-Hampton et al., 1999).

\section{Organic vegetable production in CEA with soilless media}

Compared with transplant production, few studies focus on organic vegetable production in greenhouse environments, where crops are grown for a longer time period and require greater amounts of nutrients to achieve satisfactory yield. Research on peat alternatives in conventional systems may provide useful information for organic vegetable production in soilless systems (Arancon et al., 2004; Atiyeh et al., 2000; Hardgrave and Harriman, 1995; Shaw et al., 2004). Although the same organic compliant substrates and fertility sources can be used as in transplant production, the challenge is adjusting the fertility rate and timing to maximize production. Media containing compost as substrate may continue to mineralize and release nutrients over time, therefore appropriate rates and timing of higher solubility organic fertilizers may be difficult to discern. One study investigated performance of greenhouse-grown tomatoes produced with different substrates and organic vs. synthetic fertilizer sources. The organic treatments had high EC levels, attributed to the amendments of dolomitic limestone, blood and bonemeal, and potassium sulfate added to the media (Rippy et al., 2004). However, after 4 weeks the EC levels were within acceptable levels and the authors suggested an incubation period would alleviate the problem. A 4-week incubation period for a compost-peat based mix resulted in improved quality of organic tomato transplants (Nair et al., 2011), but in this case, EC gradually increased over the study period, presumably due to potassium sulfate and as a result of mineralization- $\mathrm{N}$ in the compost. This illustrates the need for more data on mineralization rates of various organic fertility sources in a range of crops at different temperatures in controlled environments. Mineralization rates for various organic fertilizers were assessed under different temperature regimes and incubation periods (Hartz and Johnstone, 2006) and serve as a helpful guideline; however, the fertilizers were incubated with field soil and results may be different with soilless substrate.
In addition to yield, fruit quality in organic vegetable production is of interest. There is potential to market these products as functional foods with higher nutritional value to offset the costs of CEA (Falguera et al., 2012; Kubota et al., 2006). Organic amendments may result in increased quality. For example, in a greenhouse study with tomato, bone and blood meal amendments improved fruit color, and compost as a fertility amendment resulted in higher vitamin $\mathrm{C}$ content but poorer yields due to lower nitrogen availability (Montagu and Goh, 1990). Furthermore, tomatoes grown with vermicompost as the nutrient source had increased levels of calcium and vitamin C compared with conventional controls (Premuzic et al., 1998). For leafy greens such as lettuce and brassica crops (Brassica sp.), nitrate accumulation is a concern and is related to source of fertilizer, timing of nitrogen release, light intensity and duration, temperature and type of crop, and part harvested (Anjana and Iqbal, 2007). Excess nitrate consumption can have toxic effects on humans and high nitrate accumulating vegetables include leafy greens, celery, and radish [Raphanus sativus (Santamaria, 2006)]. Studies have been done measuring nitrate accumulation in organic vs. conventional production systems and generally find lower nitrate content in vegetables grown under organic practices (Woese et al., 1997). However, this might not be the case in CEA as the environments are different in these systems. Greenhouse and CEA is valued in the winter months in cool climates when field production cannot take place. Nitrate accumulation has been found to increase under conditions of low light, shorter photoperiod, and warmer temperatures (Santamaria et al., 2001), which are realistic environmental conditions for greenhouses in northern climates. More research is needed to determine nitrate accumulation on leafy greens produced organically in a variety of CEA and soilless systems to ensure levels are within safe limits (Santamaria, 2006).

\section{Conclusions}

Although market opportunities exist, there are few practical guidelines and recommendations supporting 
organic, hydroponic vegetable production in CEA. There is potential to market these products as valueadded because they can serve local markets, as functional foods, and/or potentially be marketed as certified organic. As production in urban areas continues to expand, there will be more interest in growing organic vegetables in untraditional ways, producing intensively in small spaces such as vertical walls and passive-solar heated structures. Growers often create custom media blends based on locally available materials that require trialby-error experimentation. Research opportunities in this area include 1) identifying mineralization rates and the microbial community structure and functionality for various soilless organic substrates and fertilizers, 2) optimizing timing of fertilizer applications and nutrient use efficiency, and 3) measuring crop productivity and quality in response to various organic amendments in CEA. A more decisive regulatory stance is needed by the NOP on certification of carbonbased, soilless production in CEA, and science should help inform this stance. CEA can be an efficient use of limited space and water resources for growing food, promotes food security, and can be used in urban areas and can contribute to community-based food systems.

\section{Literature cited}

Anjana, S.U. and M. Iqbal. 2007. Factors responsible for nitrate accumulation: A review. Agron. Sustain. Dev. 27:45-57.

Arancon, N.Q., C.A. Edwards, R. Atiyeh, and J.D. Metzger. 2004. Effects of vermicomposts produced from food waste on the growth and yields of greenhouse peppers. Bioresour. Technol. 93:139144.

Atiyeh, R.M., N. Arancon, C.A. Edwards, and J.D. Metzger. 2000. Influence of earth-worm processed pig manure on the growth and yield of greenhouse tomatoes. Bioresour. Technol. 75:175-180.

Boodley, J.W. and R. Sheldrake. 1977. Cornell peat-lite mixes for commercial plant growing. Cornell Info. Bul. 43.

Ceglie, F.G., M.A. Bustamante, M.B. Amara, and F. Tittarelli. 2015. The challenge of peat substitution in organic seedling production: Optimization of growing media formulation through mixture design and response surface analysis. PLoS One 10(6):e0128600, doi: 10.1371/journal.pone.0128600.

Clark, S. and M. Cavigelli. 2005. Suitability of composts as potting media for production of organic vegetable transplants. Compost Sci. Util. 13:150156.

Dixon, L. 2015. The organic hydroponics dichotomy: Can a soil-less growing system be "organic"? 14 July 2015. <http:// www.cornucopia.org/2015/03/ hydroponics-organic/>.

Despommier, D. 2011. The vertical farm: Controlled environment agriculture carried out in tall buildings would create greater food safety and security for large urban populations. J. Consumer Protection Food Safety 6:233-236.

Díaz-Pérez, J.C., J. Silvoy, S.C. Phatak, D.S. Pitchay, and R. Morse. 2008. Organic tomato transplant production in compost-amended substrate. Acta Hort. 782:241-243.

Falguera, V., N. Aliguer, and M. Falguera. 2012. An integrated approach to current trends in food consumption: Moving toward functional and organic products? Food Control 26:274-281.

Ford, C. and C. Waibel. 2009. The Northlands winter greenhouse manual: A unique, low-cost solution to vegetable production in cold climates. Garden Goddess Publ., Milan, MN.

Gagnon, B. and S. Berrouard. 1994. Effects of several organic fertilizers on growth of greenhouse tomato transplants. Can. J. Plant Sci. 74:167-168.

Greer, L. 2005. Plug and transplant production for organic systems. 4 May 2016. <https://attra.ncat.org/attra-pub/ summaries/summary.php?pub=55>.

Grunert, O., E. Hernandez-Sanabria, R. Vilchez-Vargas, R. Jauregui, D.H. Pieper, M. Pernell, M.-C. Van Labeke, D. Reheul, and N. Boon. 2016. Mineral and organic growing media have distinct community structure, stability and functionality in soilless culture systems. Microb. Biotechnol. 9:389-399.

Hardgrave, M. and M. Harriman. 1995. Development of organic substrates for hydroponic cucumber production. Acta Hort. 401:219-224.

Hartz, T.K. and P.R. Johnstone. 2006. Nitrogen availability from high-nitrogen containing organic fertilizers. HortTechnology 16:39-42.

Hodbod, J. and H. Eakin. 2015. Adapting a social-ecological resilience framework for food systems. J. Environ. Studies Sci. 5:474-484.
International Federation of Organic Agriculture Movements. 2014. The IFOAM norms for organic production and processing. 18 Apr. 2016. <http://www. ifoam.bio/en/ifoam-standard $>$.

Jensen, M.H. and W.L. Collins. 1985. Hydroponic vegetable production. Hort. Rev. 7:483-558.

Koller, M., T. Alföldi, M. Siegrist, and F. Weibel. 2004. A comparison of plant and animal base fertiliser for the production of organic vegetable transplants. Acta Hort. 631:209-215.

Kubota, C., C.A. Thomson, M. Wu, and J. Javanmardi. 2006. Controlled environments for production of value-added food crops with high phytochemical concentrations: Lycopene in tomato as an example. HortScience 41:522-525.

Kuepper, G. and K. Everett. 2004. Potting mixes for certified organic production. 2 Feb. 2016. <https://attra. ncat.org/attra-pub/viewhtml.php? id $=47>$.

Matkin, O.A. and P.A. Chandler. 1957. The U.S. type soil mixes, p. 68-85. In: K.F. Baker (ed.). The U.C. system for producing healthy container-grown plants. California Agr. Expt. Sta., Ext. Serv. Manual 23.

Mininni, C., M.A. Bustamante, E. Medina, F. Montesano, C. Paredes, A. PérezEspinosa, R. Moral, and P. Santamaria. 2013. Evaluation of posidonia seaweedbased compost as a substrate for melon and tomato seedling production. J. Hor. Sci. Biotechnol. 88:345-351.

Montagu, K.D. and K.M. Goh. 1990. Effects of forms and rates of organic and inorganic nitrogen fertilisers on the yield and some quality indices of tomatoes (Lycopersicon esculentum Miller). N.Z. J. Crop Hort. 18:31-37.

Montri, A. and J.A. Biernbaum. 2009. Management of the soil environment in high tunnels. HortTechnology 19:34-36.

Nair, A., M. Ngouajio, and J. Biernbaum. 2011. Alfalfa-based organic amendment in peat-compost growing medium for organic tomato transplant production. HortScience 46:253-259.

Nelson, P.V. 2012. Greenhouse operations and management. 7th ed. Prentice Hall, Upper Saddle River, NJ.

Ozores-Hampton, M., C.S. Vavrina, and T.A. Obreza. 1999. Yard trimmingbiosolids compost: Possible alternative to sphagnum peat moss in tomato transplant production. Compost Sci. Util. 7: $42-49$.

Peet, M.M., E.S. Larrea, and C. Harlow. 2008. Tomato seed germination in 
organic mixes: Role of EC and mix components. Acta Hort. 797:393-398.

Premuzic, Z., M. Bargiela, A. Garcia, A. Rendina, and A. Iorio. 1998. Calcium, iron, potassium, phosphorus, and vitamin $\mathrm{C}$ content of organic and hydroponic tomatoes. HortScience 33:255-257.

Raviv, M. 2005. Production of highquality composts for horticultural purposes: A mini-review. HortTechnology 15: 52-57.

Reis, M., F.X. Martinez, M. Soliva, and A.A. Monteiro. 1998. Composted organic residues as a substrate component for tomato transplant production. Acta Hort. 469:263-273.

Rippy, J.F.M., M.M. Peet, F.J. Louws, P.V. Nelson, D.B. Orr, and K.A. Sorensen. 2004. Plant development and harvest yields of greenhouse tomatoes in six organic growing systems. HortScience 39: 223-229.

Russo, V.M. 2005. Organic vegetable transplant production. HortScience 40:623628.

Santamaria, P. 2006. Nitrate in vegetables: Toxicity, content, intake and EC regulation. J. Sci. Food Agr. 86:10-17.

Santamaria, P., A. Elia, and M. Gonnella. 2001. Ways of reducing rocket salad nitrate content. Acta Hort. 548:529-537.

Shaw, N.L., D.J. Cantliffe, J. Funes, and C. Shine. 2004. Successful beit alpha cucumber production in the greenhouse using pine bark as an alternative soilless media. Hort Technology 14:289-294.
Sikora, L.J. and R.A.K. Szmidt. 2001 Nitrogen sources, mineralization rates, and nitrogen nutrition benefits to plants from composts, p. 287-305. In: P. Stofella and B. Kahn (eds.). Compost utilization in horticultural cropping systems. CRC Press, Boca Raton, FL.

Specht, K., R. Siebert, I. Hartmann, U.B. Freisinger, M. Sawicka, A. Werner, S. Thomaier, D. Henckel, H. Walk, and A. Dierich. 2014. Urban agriculture of the future: An overview of sustainability aspects of food production in and on buildings. Agr. Human Values 31:33-51.

Sterrett, S.B. 2001. Compost as horticultural substrates for vegetable transplant production, p. 227-240. In: P. Stofella and B. Kahn (eds.). Compost utilization in horticultural cropping systems. CRC Press, Boca Raton, FL.

Treadwell, D.D., G.J. Hochmuth, R.C. Hochmuth, E.H. Simonne, L.L. Davis, W.L. Laughlin, Y. Li, T. Olczyk, R.K. Sprenkel, and L.S. Osborne. 2007. Nutrient management in organic greenhouse herb production: Where are we now? HortTechnology 17:461-466.

Tyson, R.V., D.D. Treadwell, and E.H Simonne. 2011. Opportunities and challenges to sustainability in aquaponics systems. HortTechnology 21:6-13.

U.S. Department of Agriculture (USDA). 2010. Crops Committee recommendation: Production standards for terrestrial plants in containers and enclosures (greenhouses). 1 Feb. 2016. <http:// www.ams.usda.gov/sites/default/files/ media / N O P $\% 20$ Fin al $\% 20$ Rec $\%$ 20 Production $\% 20$ Standards $\% 20$ for $\%$ 20Terrestrial\%20Plants.pdf $>$.

U.S. Department of Agriculture (USDA). 2012. Organic production survey, 2008. 28 Jan. 2016. <www.agcensus.usda.gov/ Publications/Organic_Survey/>.

U.S. Department of Agriculture (USDA). 2015. Organic vegetables, potatoes, and melons grown under protection harvested-certified and exempt organic farms: 2014. 28 Jan. 2016. <www.agcensus. usda.gov/Publications/Organic_Survey/>.

Woese, K., D. Lange, C. Boess, and K.W. Bögl. 1997. A comparison or organically and conventionally grown foods-results of a review of the relevant literature. J. Sci. Food Agr. 74:281-293.

Wortman, S.E. and S.T. Lovell. 2013. Environmental challenges threatening the growth of urban agriculture in the United States. J. Environ. Qual. 42:1283-1294.

Zhang, J.-H., G.-M. Tian, G.-D. Zhou, M.-M. He, F. Wang, and J.-H. Yao. 2013. Evaluation of organic solid wastes composts as peat substitutes for seedling production. J. Plant Nutr. 36:1780-1794.

Zheng, Y., M.A. Dixon, and G. Ferguson. 2011. Organic greenhouse vegetable production in Canada: Challenges and opportunities. Acta Hort. 893:11951200. 